\section{Problems of the Gas Industry}

ON October 24 Mr. A. E. Sylvester addressed the Fuel Luncheon Club on some immediate problems of the gas industry in Great Britain. The speaker, as managing director of the Gas Light and Coke Co., London, spoke on administrative rather than technical problems. He appealed for freedom of choice for the consumer of fuels, while recognizing the need for some sort of control to see that prices are reasonably related to cost of supply taking into account all the circumstances. The gas industry includes far too many small units, which, though possibly manufacturing gas satisfactorily, are unable to maintain the technical staffs adequate to give the service to consumers which present-day conditions require. The aggregation of the industry into larger groups would provide openings for more specialist technicians, while a national pension scheme would favour a freedom of movement which would be beneficial both to themselves and to an industry national in scope. Mr. Sylvester pleaded for sales tariffs which deal justly as between one type of consumer and another. It is sound policy to relate changes to cost as closely as circumstances permit, otherwise one article has to subsidize another. When gas is supplied to a factory, the charge must cover not only manufacture but also capital costs up to the works, and little more. For domestic fuel the charge must go further, covering the heavy costs of services to the consumer. The resultant charges must differ, otherwise justice is not done as between consumers. It was emphasized that gas is a refined fuel and is used because of the service it gives; this emphasis implying the necessity for a high standard of service throughout the country.

\section{A Study of Reason}

Prof. H. J. Paton, in his lecture to the British Academy entitled "Can Reason be Practical ?" (London : Oxford University Press, 1944. 4s. net), defends against recent attacks the view that moral principles are rules of reason. Some have maintained that moral judgments are merely the expression of private emotions or merely the result of pressure of the social environment, and that the attempt to justify them is 'rationalization' in the bad sense. Against these critics he argues that if they would only apply their theories to their own judgments they would see their absurdity. Those who oppose instinct or intuition to reason are making a false antithesis. The infant sucks by instinct, but ought to realize later that it was the most reasonable thing to do in the circumstances. Prof. Paton develops the positive side of his argument from the starting point that human conduct should at least be intelligent, that is to say, consistent and orderly, so that means are adapted to ends and conflicting impulses subordinated. The principles of practical reason are the result of taking this notion of order and consistency as far as it will go and generalizing as completely as possible. The rest of Prof. Paton's exposition is on Kantian lines, but with some useful clarification and, perhaps, some modification in the direction of what Kant ought to have said.

\section{Collaboration with French Men of Science}

THE executive committee of the Association of Scientific Workers has sent a message of greeting to French men of science who have taken part in the Resistance Movement in France. "It looks forward to close collaboration between the scientific workers of both our countries for the progress of our common aims : the development of science and its use to advance the living and cultural standards of all peoples". The Association des Travailleurs Scientifiques, formed from the Resistance Movement a few days after the liberation of France, has acknowledged this greeting conveyed through Prof. JoliotCurie. "In its refusal to accept the defeat of France as final and to submit to the subsequent German domina. tion, the Resistance movement has, since 1940, been animated by that same spirit which inspired the entire British nation when it decided to continue the struggle. This community of ideas concerning the conduct of the war must continue in the maintenance of peace. The great contribution made by scienee to the national defence can be continued in the economic and social spheres of the peace-time world organization of to-morrow."

\section{Announcements}

SIR HaRold Hartiey will deliver the Lavoisier Bicentenary Lecture of the Royal Society on November 16 , at 4.30 p.m.

The Club for Research on Ageing (c/o Department of Zoology and Comparative Anatomy, University, Oxford) has received from Lord $\mathrm{Nu}$, eld a donation of $£ 3,900$, which will enable Dr. V. Korenchevsky to continue his gerontological investigations for a period of three years. Clinical trials of the effects of vitamins on aged persons at the Tooting Bec Hospital will be finished at the end of the year. These were rendered possible during the last two years by substantial grants from Lord Nuil.eld and the Nuri eld Foundation. The Club expresses its heartfelt thanks for these benefactions and is also very much indebted to the London County Council for most valuable co-operation.

THE Trustees of the Miners' Welfare National Scholarship Scheme invite applications for a limited number of university scholarships and exhibitions. Candidates must be either workers in or about coal mines in Great Britain, or sons or daughters of such workers, and normally should not be less than seventeen years of age on January 25. Forms of application and full particulars may be obtained from the Secretary, Miners' Welfare National Scholarship Scheme, Ashley Court, Ashtead, Surrey. Applicants for forms must state whether they apply as workers in or about mines or as children of such workers; those who come within both categories should apply as workers. Completed applications must be received by January 25 .

THE Council of the Institution of Civil Engineers has set up a special War Service Committee to deal with the cases of prospective candidates for election whose engineering training has been interrupted by the War, with a view to these candidates being advised in regard to the periods of practical training and/or engineering experience and the examination qualifications they will be required to obtain before the Council will consider them qualified for election to corporate membership of the Institution. Intending candidates for election who are serving in H.M. Forces, or who have been directed into work of national service, and who were less than thirty-one years of age on November 1, should apply to the secretary for particulars. 